\title{
Challenges for business change in district heating
}

Kristina Lygnerud

\begin{abstract}
Background: The Swedish district heating sector is successfully transitioning to a low-carbon energy system. The industry has expanded since the 1950s and currently meets more than half the Swedish heat demand. The heat market was deregulated in 1996, and thereafter, companies have been exposed to an increasing number of challenges related to technology, institutional factors and market. Since municipal ownership dominates, municipal companies must manage these challenges to ensure future competitiveness. However, theory suggests that business change is difficult when the current model is still working. To date, Swedish district heating companies have revisited their price models and customer perceptions. There is limited knowledge on how the business challenges are managed and on the management strategy's impact on the business. In this paper, new knowledge is generated regarding how the customer and resource-oriented sides of the municipally owned district heating business in Sweden are changing.
\end{abstract}

Methods: A case study approach was adopted. Data were collected by interviews and by review of the national research programme on district heating (Fjärrsyn). The programme served as a proxy for frontline research on Swedish district heating. The data were analyzed through the business model canvas framework.

Results: Changes to meet external pressures are identified on the customer side of the business model, but changes are also spreading to other parts of it. However, the key resource component (distribution networks and production unit) and its logic of economics of scale are unchanged and dominate. The logic is not compatible with shrinking heat demand; nevertheless, it is preferred.

Conclusions: It is concluded that external challenges have resulted in changes in the customer side of the business model. However, the largest challenge is the transformation of key resources. Accounting for external challenges extends the life of the current business model, but it is not increasing competitiveness. The prolonged life creates a window of opportunity for the companies to begin the needed transformation of their key resources. If the transformation is successful, district heating will have a role in the future energy system. If the transformation is not undertaken, the future is less certain.

Keywords: District heating, Business, Challenge, Energy transition, Sweden

\section{Background}

Fossil fuels are the dominant energy sources for heating [1], and this is neither sustainable from the point of view of the climate nor from the point of view of stable supply. District heating systems can reduce the usage of fossil fuels for heating as they access renewable energy sources [2] and industrial excess heat [3]. Heating and cooling are the largest energy sectors in the EU and represent half of the final energy consumed. Some $20 \%$ of

Correspondence: Kristina.lygnerud@hh.se

Halmstad University, PO BOX 823, Halmstad SE 30118, Sweden the fuels used in the heating sector are from renewable sources. Hence, to reduce the dependence on imported energy, to lower energy costs and to decarbonize the European energy system, expansion of district heating is important. There is a significant potential for district heating growth since only $9 \%$ of European heat is currently provided by district heating [3]. Countries where the growth potential is largest are Austria, Germany [4], France and Italy [5].

In Sweden, district heating dominates the heat market with a market share of $55 \%$, and district heating systems 
are in place in all major cities and towns (there are about 500 systems in Sweden) [6]. Oil and other fossil fuels for heating have been gradually removed over the past 50 years, and the Swedish district heating system is successfully transforming into a low-carbon system [7]. Sweden is, for example, the country that has the largest percentage of industrial heat recovery in its district heating systems in the world [8]. This dominant position of district heating in the heat market is, however, being challenged. In 1996, the Swedish heat market was deregulated. Prior to this, the largest challenge to the district heating industry was to improve its production technology to meet the increasing demand [9], but since 1996, the industry has had to cope with challenges beyond technology. Examples of institutional challenges are a new district heating law (2008), the threat of price regulation (2009) and third party access (2009). Market challenges are reflected in the increasing competition (notably from heat pumps), lower heat demand (as a result of energy efficiencies and warmer climate) and revised customer demands [10-12].

Expansion of district heating in Europe also faces market challenges, and while there are some differences, there are also some similarities with the challenges facing the Swedish district heating industry. Four examples are provided below. Regarding competition, the traditional use of gas boilers is the largest competition for district heating in Europe [3], while in Sweden, competition comes from heat pumps. Addressing energy efficiency, lower energy demand will, after the renovation of the building stock, become as challenging to European district heating providers as it already is to Swedish. Financing of new district heating in Europe is not easy since public finance is not a given [3]. This is in contrast to the Swedish situation where financing of new district heating is predominantly undertaken by municipalities. Last, industrial heat recovery is discussed in the EU. Sweden is at the forefront of such heat recovery, but there is an additional potential [13-15]. Industrial heat recovery necessitates cooperation often making the heat provider both a consumer and a provider (prosumer) of district heating, a challenge which is more common amongst Swedish district heating providers than their European counterparties [16, 17].

The case of Swedish district heating is an example of a successful national and long-term transition to a lowcarbon energy system. However, energy transition is not sufficient to remain competitive. Attention also needs to be given to the management of business challenges beyond the vision of being fossil-free. Even though the challenges faced in Sweden are not identical to the expansion of district heating in Europe, the experience from the Swedish heat sector should be useful to decision-makers desiring to keep the low-carbon district heating system competitive, to other countries shifting their heat generation from fossil fuels to renewable energy sources, to district heating providers and to researchers in business change.

Swedish district heating companies act in a deregulated market and must effectively manage dynamic challenges to remain competitive. Theory suggests that business change is difficult when the current model still works [18-20]. It is not known if Swedish district heating companies are locked-in to the current business models, and there is only limited information on how the companies manage business challenges. In addition, the impact that the chosen management strategy has on the customer interaction, the key resources and the important partnerships, all remain unexplored. In view of this, the research question addressed in this paper is as follows: How does the management of business challenges impacts the business of Swedish municipal district heating?

This paper is structured in four sections: Background, Methods, Results and Conclusions. In the first section, the Swedish case of a long-term and national transition towards a low-carbon energy system is presented. Since energy transition in itself is not sufficient for competitiveness, the research question of how the management of business challenges impacts the business of Swedish municipal district heating is introduced. Thereafter, district heating, the growth of district heating in Sweden, known challenges to district heating and the theoretical framework of the study are elaborated. In the second section, the two methods applied to collect data are outlined. Both interviews and a review of research projects have been conducted. The model of analysis is the business model canvas which is explained. In the third section, results are provided and discussed. The results from the interviews and from the review are presented separately. The last section draws on the results to conclude on business development in Swedish district heating companies. The main conclusion is that external challenges have resulted in changes in the customer side of the business model. The limited change to the key resource component is, however, the largest challenge for the future.

\section{Background: district heating and its expansion in Sweden}

District heating companies often use locally available heat sources for heat generation [21]. Examples of heat sources are fossil fuels, biomass, geothermal heat, waste for incineration and excess heat. Heat and power are frequently produced jointly in the so-called combined heat and power plants. Traditionally, heat is distributed from a central production unit to customers through a network of pipes [2]. The industry is currently undergoing a successful transition away from fossil fuels, and it is even 
claimed that the expansion of district heating is one of the most important explanations as to why Sweden is achieving success in its carbon dioxide reductions [22].

The Swedish heat market is shaped by institutional factors including municipal initiatives, national policies and regulations [2]. In the 1950s and 1960s, municipalities aimed at enabling efficient electricity production in combined heat and power plants which were seen as a complementary electricity source to hydropower [23]. In the 1960s and 1970s, district heating expansion coincided with massive housing construction. One million dwellings were erected between 1965 and 1974 within the Million Homes Programme [24]. Furthermore, as a result of the oil crisis in 1973-1974 and 1978-1979, Sweden launched its first energy policy in 1975 [2] and increased funding to energy research and development [25]. District heating was now of national, rather than just municipal, interest. Government subsidies were provided for replacing oil boilers with district heating [26]. There was also a shift from oil in the district heating companies to alternative heat sources such as coal, wood fuels, peat, municipal solid waste, heat pumps, electric boilers and industrial waste heat [2].

Further progress was made as Sweden's first climate target was established in 1988, aimed at reducing carbon dioxide emissions, and thus, sustainable energy systems became a priority [27]. A carbon dioxide tax was introduced in 1991 from which biomass and peat were exempted. This development made biomass the most cost-efficient fuel for heat production, and the usage of biomass in district heating grew fourfold between 1990 and 1996. After 2000, the ban on depositing organic waste in combination with energy taxation incentivized many municipalities to invest in waste incineration plants with heat recovery [2]. Currently, biofuels and waste are the most common fuels used in district heating [28]. Against this background, the Swedish district heating market expanded for decades leading to the current, large market share. Increasing demand, in combination with national policy, also triggered rapid technological development and the switching to different fuel sources.

\section{Background: known challenges to district heating in Sweden}

The known challenges to district heating providers in Sweden can be placed in three categories. These are technological development, institutional changes and market challenges as shown in Table 1. Considering technological development, there is still room to improve existing production and distribution of heat [29-31]. However, most improvements are incremental and generate short-term, rather than long-term, gain. This is reflected in the research conducted in the national
Table 1 Known challenges to Swedish district heating companies

\begin{tabular}{ll}
\hline Category of challenge & Example of challenge \\
\hline 1. Technological development & - Value of incremental development \\
& - Locked into current technology \\
& - New technology (low temperature) \\
2. Institutional change & - Deregulation of market \\
& - District heating law \\
& -Threat of price regulation \\
& -Third party access assessments \\
3. Market challenges & - Competition (heat pumps) \\
& - Declining demand \\
& - Changing customer requests \\
\hline
\end{tabular}

programme of district heating research (2013-2017). In a synthesis of the research from the programme, it was identified that the focus of the research in the most recent programme period was on known challenges and on incremental improvements of the current technology [32]. Sweden has well-developed district heating systems that are primarily adjusted to incineration of waste and biofuels. The established district heating technology, referred to as the third generation, is well established, and there is little incentive for switching to heat sources other than waste and biofuels. There is thus a risk that companies are locked-in to the current technology [7, 32]. Taking into account that there are alternative uses for biofuels other than incineration, and that the amounts of waste are to be reduced in Europe, identifying alternative heat sources is relevant in the long term. Alternative heat sources that are abundant in urban areas are generally low temperature and may be generated from specific commercial processes or from structured operations that are undertaken daily. Cooling from data centres and sewage water heat recovery are known examples [33-39]. There is a new technology currently being developed to take advantage of such lowtemperature heat sources [40].

Carbon dioxide reductions are important in the decision-making process when undertaking a technology improvement, reflecting the long-term aim of the industry to become fossil free, a goal that is close to being attained. However, low-temperature heat sources are fossil free, thus outdating the historic vision of a fossil-free heat source. Therefore, challenges for technological development are to correctly evaluate the benefit of incremental developments and to identify when it is time to move from the safety of the current, cost-efficient, close to zero carbon technology to more ambitious solutions.

The industry has faced a number of institutional changes since the deregulation of the heat market in 1996. Three key events are the district heating law, price discussions and discussions on third-party access to the distribution networks. Deregulated, municipal energy companies were urged to operate in a "business-like" fashion [41]. Misconduct with regard to the price development post-deregulation resulted in a district heating 
law in 2008. It has since become evident that the law is construed in such a way that a distinction is made between personal trust and trust for the district heating system, which creates a negative bias towards the district heating system. This bias is a challenge that reinforces the negative perceptions surrounding the natural monopoly status of district heating companies [42]. This lack of trust erodes the competitiveness of district heating compared to other heating alternatives. Regarding district heating price, the Swedish Competition Authority advocated regulation of district heating price in 2009 . Later, in 2013, it was revealed in a report from the authority that it is difficult to arrive at a fair cap for a market that is as heterogeneous as the Swedish heat market. Additionally, ruling out price discrimination for certain customer segments can actually obstruct welfare improvement outcomes. This is a factor that militates against the desired property of price regulation in that customers in the same category should pay the same price [43].

The heat market has not yet been regulated in terms of price. However, in response to this challenging discussion on the subject, the district heating industry has initiated a voluntary dialogue with their largest customers. This process is called "the price dialogue" and is one way to proactively engage in dialogue with customers on the topic of district heating price. Currently, 37 district heating companies are members of the dialogue including the three largest district heating providers in Sweden (Vattenfall, Fortum and E.ON). The dialogue has existed since 2013 and replaces an earlier initiative to create transparency (the REKO initiative). As a result of the increased attention on price, much attention has been given to the price models of district heating companies [44]. There is an ongoing tension in that customers want pricing models favouring energy efficiency. This reduces the possibility of directly charging customers for the fixed costs of the district heating companies [45].

The third key example of institutional changes is that of third-party access to the distribution networks. A government inquiry was launched in 2005 and concluded in 2009 recommending that district heating providers are obliged to assess the economic viability of third-party access if a third party wishes to access the distribution network [46]. If the assessment indicates that the proposal would result in a negative investment, the district heating companies have the right to decline the heat from the third party.

Remaining in the market is a challenge since the competition for heat customers is increasing, heat demand is decreasing and the characteristics of customer demand are changing. The main competitor for the industry is heat pumps. Heat pumps and electrical heating jointly meet one third of the Swedish heat demand, and historically, heat pumps have been successful in small, private houses, whereas district heating dominates in multi-family dwellings and public/private large premises. The competition is fierce in the small house segment as reflected in the public press where there are discussions about the rights of municipalities to condition the heating alternatives of homeowners in newly built, singlefamily homes [47, 48]. Disapproval of the natural monopoly status of municipal district heating and policy development incentivizing purchased energy over used energy [49] have made heat pumps a competitive alternative to district heating [7]. It is assumed that heat pumps will continue to take market share from district heating [50]. A trend towards installations of larger heat pumps is also identifiable. For example, the Swedish environmental governance agency has identified installation of new, larger heat pump installations in the area of Stockholm [51]. One detectable response to the increased competition from heat pumps is that many Swedish district heating companies are revisiting their income structure and price models, introducing seasonal or effect-based models [51]. Another district heating market challenge is that the growth rate of the heat market is reducing [12]. One reason for this is the lower heat demand triggered by improved energy efficiency and the warmer climate $[11,52]$. A further reason is that the heat market is becoming saturated; indeed, the heat market has been described as approaching a stagnation phase [53].

A final example of the theme of market challenges is new customer demands. Customers know that the district heating companies act in a competitive market, and hence, customers have new demands. One important demand is transparency, which is reflected in the attention given to the price. Another is the support in identifying efficient solutions to meet the needs of the customer, including energy efficiency measures [44]. Since 2015, monthly measurement and invoicing to customers has become mandatory which means that large amounts of operational data are now available. This, in combination with progress in the field of digitalization, can provide a better overview of the production/distribution and of the end-consumption of district heating. In the future, this can result in heat "on-demand" and a heat service of higher quality being delivered to the customers $[54,55]$.

As mentioned previously, prosumers also form part of the Swedish district heating sector. Approximately, 9\% of the heat in Swedish district heating comes from industrial waste heat cooperation [8]. This is the highest level of industrial waste heat recovery in the world. Most of the prosumers in Swedish district heating systems are the result of customer-driven development. The driving forces have either been to make a profit from a valuable resource that is otherwise lost, to be eligible for different 
energy certificates by showing that a certain amount of energy is produced in-house or to enforce the sustainability dimension of the brand [32].

The many market challenges, as described above, point to the time for one-size-fits-all solutions being over. In Table 1, the categories of known challenges to Swedish district heating companies are listed, and examples of these challenges are provided.

\section{Background: theoretical framework}

Customers (value, relationships, segments), resources (infrastructure, activities, partners, logistics) and the cost/income structure resulting from customer and resource choices are generic elements of business models $[18,56-59]$. While there is no universal definition of what a business model is, they can be a source of competitive advantage [60-64] at least initially before they are imitated [59]. Business models are not to be confused with product market strategy [65] since business models describe how different pieces of a business fit together but do not account for choices made to meet competition [63]. Business models do, however, seem to reflect strategy [60], but the two are not equivalent [59, 61-65]. Business models are also different from products, companies, industries, networks, technology, internal organization and value chains [56].

It is known that business models develop over time, and there are studies promoting the idea that business model development is a tool for corporate renewal $[19,50,66-68]$. Successful companies, it is argued, account for changing preconditions in the surrounding world through developing their business models. Good models secure long-term competitiveness and survival $[18,67,69,70]$. There is no consensus on a definition of what a business model is or on how business model development is realized. Some researchers advocate that business model development is the result of a systematic and structured process [18, 71, 72]. Others claim that it stems from trial and error [18, 19, 73]. Whether companies develop their business models as a response to external pressures, internal changes or a combination of both is not clear $[66,71,74,75]$.

There are known barriers to business model development. For example, different parts of a business model are interconnected [59] which creates a situation where present organization hinders the development of a future business model [18-20]. Another barrier to business model development is that outdated business logic about cost and revenue are taken for granted, for example, the assumption that economies of scale are preferable to other alternatives, even though this assumption is no longer valid [59]. Yet, another hindrance for business model development is that only certain information is perceived as important due to the business logic of the organization. Incoming information is filtered in such a way that only limited information reaches those who make business model decisions [74]. Uncertainty about desired future development paths constitutes a further obstacle for business model development since it is difficult to assess which business models are suitable for the future if the future strategy is unknown [18].

Narrowing the scope of business models to studies that are of relevance to understanding Swedish district heating companies, a study of German utilities and how they innovate their business models for sustainable energy is useful. From this study, two generic business models are available [76]. One is referred to as the utility-side renewable energy business model. Its value proposition is a bulk generation of electricity. The other business model is referred to as the customer-side renewable energy business model. This model relates to energy generation in small-scale systems close to the point of consumption and uses distributed generation based on technologies such as solar photovoltaics, micro-wind turbines and micro-combined heat and power systems [76]. In another study, exploring business models amongst heat entrepreneurs in Finland, ownership is taken as a proxy for business model determination [77]. Five companies with different ownership forms, public company, publicprivate partnership, private cooperative, network model of large enterprise and energy service companies (ESCOs), result in five different business models with different "earning" logic. The logic are as follows:

(i) Secondary/third party financing which reflects that an entrepreneur unlocks the customer's resources for other purposes. If the customer is a municipality, funding is unlocked for other municipal undertakings such as healthcare and schools.

(ii) Safeguarding the market which means that the heat demand is stable, and long-term contracts are present with reliable customers such as municipalities.

(iii) Value added by holistic value chain management which reflects that the more activities the entrepreneur can execute, the better the profitability is. An example is when one single entrepreneur provides both fuel supply and heat production.

(iv) Complementary partnerships which reflect situations where partners attend to the activities where they have expertise. This can be the case in a cooperative organization with specialized partners.

(v) Networking and subcontracting which means that some of the tasks are subcontracted and that the subcontractors can benefit from the network, scale and reliability of the principal company. 
The study identified that subcontracting was undertaken independently of ownership and that all companies other than the ESCOs were safeguarding the market [77]. The business model of solid waste management was explored in a Swedish study, and it was shown that three value-creating activities were undertaken. First, there was a public service mission, creating value for those in need of getting rid of waste and authorities who were legally required to handle waste. Second, there was processing, including efficient and environmentally sustainable management of waste and, when possible, reuse and recovery. Third, marketing activities were undertaken to realize the economic value of the output of the processing activity [78]. In a further two studies, the significant role of national policymaking in the development of business models currently used in district heating was addressed [2, 7]. The studies pointed out that the current business "regime" is locked-in to supply dominated heat production aimed at sustaining the production of heat itself, while there is limited attention on reducing heat demand.

\section{Methods}

District heating companies are exposed to different challenges to varying extents. Which challenges are the most important, and how they are managed, is a complex situation to investigate. In this paper, two methods were used to collect data in order to analyze these complexities. The first method involved conducting interviews with business development professionals in Swedish district heating companies. The second method involved a review of the most recent research performed in the national district heating programme (Fjärrsyn). This research was taken as a proxy for the frontline of Swedish district heating research and should, as such, reflect challenges to district heating providers.

\section{Methods: interviews and national research programme review}

A business model is complex in that it is composed of several interrelated parts. Understanding the impact of management on different parts of the model necessitates in-depth information. It was not possible to gather indepth data from all Swedish district heating companies, and hence, a case study was made. Five Swedish district heating companies were chosen based on three specific criteria. Companies that fulfilled the criteria were considered likely to be forerunners in terms of managing the challenges they are exposed to. Therefore, the selected cases can be viewed as critical cases, from which, the wider district heating community can learn how to manage the challenges that the industry faces [79]. The first criterion was that the companies should have a long-term incentive to work on the development of their business models. District heating investments are longterm with an operational lifetime of decades. Companies that have recently undertaken or are undertaking investments in new district heating production units were therefore assumed to have an incentive for long-term business model development. The second criterion was that the cities where the companies were located should be stable or growing in terms of population size. The continued expansion means that the companies have time to actively work with business model development for future success rather than focusing on short-term cost-cutting activities. The third criterion was that the companies should have an evidenced capacity of progressive thinking. One company recently became the district heating company of the year; one company is exporting its knowledge; one company is heavily engaged in the city's transformation roadmap for the year 2035; one company resorts extensively to industrial waste heat recovery; and one company is investing in an unconventional production unit. In Table 2, the companies included in the case study are presented. The five case study companies are amongst the 15 largest district heating companies in Sweden in terms of annual turnover.

The policy has shaped the development of the heat market, the current district heating company business model and its logic. Hence, when selecting the population to study, policymakers were of relevance. Past impact does not, however, mean that the policymakers have knowledge about the actions and adjustments made by the companies in their daily operations. In this study, answers were sought to understand how companies adjust to technical, institutional and market challenges. Chief executive officers (CEOs) and business developers should be in a better position to provide information about the company management strategies needed to handle challenges than policymakers. The target group chosen for the interviews included CEOs and business developers. A semi-structured interview guide, allowing for questions arising during the interview to be addressed [80], was elaborated based on the business model canvas components [58]. Each interview lasted between $45 \mathrm{~min}$ and 1 hour. Notes were taken during

\begin{tabular}{|c|c|c|c|}
\hline $\begin{array}{l}\text { Respondent } \\
\text { company }\end{array}$ & $\begin{array}{l}\text { New production } \\
\text { unit commissioned }\end{array}$ & $\begin{array}{l}\text { Population } \\
\text { growth of the city } \\
(2000-2016)(\%)\end{array}$ & $\begin{array}{l}\text { Annual turnover } \\
\text { MSEK (2016) }\end{array}$ \\
\hline 1 & Under construction & +15 & 920 \\
\hline 2 & 2010 & +19 & 1400 \\
\hline 3 & 2014 & +10 & 1220 \\
\hline 4 & 2013 & +21 & 2600 \\
\hline 5 & 2014 & +17 & 1200 \\
\hline
\end{tabular}


the interviews, and these were summarized in writing after each interview.

No interview questions were included to find out more about the cost and revenue streams in the five case study companies. The reason was that all respondents, when they were first contacted and asked to participate in the study, were informed that they would not disclose this kind of information.

To identify challenges to the district heating industry, it is relevant to review the Swedish frontier of district heating research, which has a long history in the country. Since 1975, there have been different programmes dedicated to district heating research. The most recent national programme on district heating, Fjärrsyn, covered the period 2007-2017. Its most recent programme period ran from 2013 to 2017 and encompassed 34 research projects. Fjärrsyn was jointly financed by the Swedish district heating industry and the Swedish Energy Authority. The output from the latest programme period was taken as a proxy for the current Swedish district heating research frontier. To identify additional information regarding challenges to the business of district heating, the 34 projects involved in the research were reviewed.

\section{Methods: the model of analysis}

The business model canvas [58] was used as the model of analysis in this study. It provides a framework composed of nine blocks and is widely used for understanding business models. It was developed jointly by academic researchers, government officials, professionals from different industries, analysts from different sectors and consultants interested in business modelling. The canvas has been selected for this study since it is a framework that explicitly addresses the components that are deemed relevant for understanding business change in district heating. Additionally, it is a framework that has been developed jointly between academics and practitioners making it suitable for explaining the findings to district heating researchers, policymakers and practitioners. The canvas is illustrated in Table 3.

Four of the blocks address the customer, outlining the customer segment, the channels used to reach the customers, customer relationships and the value proposition. Three of the blocks consider activities undertaken to deliver the value, the resources needed for value creation and the imperative partnerships for delivery of the product or service. The last two blocks outline the cost structure undertaken by the business and the income structure of the realized sales.

The interview guide was built around the components of the canvas. The questions were elaborated based on knowledge about the business models in Swedish district heating companies dating back to 2008 [10], 4 years of experience of the author working with strategy and business model development in the industry (2011-2015) and based on known challenges for the Swedish district heating industry. In the interviews, all blocks except cost and income structure were addressed as noted above.

Knowledge about conventional business models in district heating, data from the interviews and information from the reviewed research projects were framed using the canvas. An analysis was then conducted to identify where development in the business models could be detected compared with the conventional district heating business models. In Table 4, the conventional features of district heating business, as identified from the literature, are presented.

On the customer side of the district heating business model, the largest customer segment is business-tobusiness. The business logic is based on economies of scale and a strategy of push, rather than pull, towards the customers; the business models are also utility-sided. Regarding the infrastructure, the key resources are the production units and distribution networks. The necessity to cover fixed costs is reflected in the price model. In terms of key partnerships, it is known that fuel providers are crucial to the success of district heating businesses [10].

\section{Results and discussion}

The results from the interviews are presented in two sections: customer interaction and use of resources. At the end of each section, the results of the review of the 34 research projects are also included. All results are jointly inserted into the business model canvas and are summarized in Table 5.

\section{Results: customer interaction (from the interviews)}

In the business model canvas, the customer-oriented blocks are customer value, customer segment, customer

Table 3 The business model canvas framework

\begin{tabular}{|c|c|c|c|}
\hline \multirow[t]{2}{*}{$\begin{array}{l}\text { Key partnerships } \\
\text { "Who can help you"? }\end{array}$} & $\begin{array}{l}\text { Key resources } \\
\text { "What do you need"? }\end{array}$ & $\begin{array}{l}\text { Customer value } \\
\text { Answers the question of "what do you do"? } \\
\text { This is where the analysis starts }\end{array}$ & $\begin{array}{l}\text { Customer segment } \\
\text { "Who do you help?" }\end{array}$ \\
\hline & $\begin{array}{l}\text { Key activities } \\
\text { "How do you do it"? }\end{array}$ & $\begin{array}{l}\text { Customer channel } \\
\text { "How do you reach them?" }\end{array}$ & $\begin{array}{l}\text { Customer relationship } \\
\text { "How do you interact?" }\end{array}$ \\
\hline $\begin{array}{l}\text { Cost Structure } \\
\text { "What will it cost"? }\end{array}$ & & $\begin{array}{l}\text { Income Structure } \\
\text { "What is the return"? }\end{array}$ & \\
\hline
\end{tabular}


Table 4 The conventional features of Swedish district heating businesses

\begin{tabular}{|c|c|c|c|}
\hline \multirow[t]{2}{*}{$\begin{array}{l}\text { Key partnerships } \\
\text { Fuel providers }\end{array}$} & $\begin{array}{l}\text { Key resources } \\
\text { Production unit } \\
\text { Distribution network }\end{array}$ & $\begin{array}{l}\text { Customer value } \\
\text { Provider of heat and hot water (utility) }\end{array}$ & $\begin{array}{l}\text { Customer segment } \\
\text { Business-to-business (largest segment) } \\
\text { Private homeowners }\end{array}$ \\
\hline & $\begin{array}{l}\text { Key activities } \\
\text { Production } \\
\text { Distribution } \\
\text { Maintenance }\end{array}$ & $\begin{array}{l}\text { Customer channel } \\
\text { Invoicing } \\
\text { Campaigns }\end{array}$ & $\begin{array}{l}\text { Customer relationship } \\
\text { Provider to consumer (push) }\end{array}$ \\
\hline $\begin{array}{l}\text { Cost structure } \\
\text { Large fixed costs }\end{array}$ & & $\begin{array}{l}\text { Income structure } \\
\text { Fixed }\end{array}$ & \\
\hline
\end{tabular}

relationship and customer channel. In the customer segment, no changes in response to the industry challenges were identified from the interviews. In the five case companies, it is still the professional customers that generate the largest sales. All five companies also have private homeowners as customers, but the sales generated from these are limited.

Regarding customer value and customer relationship, a significant change was detected compared to the conventional district heating business model. With regard to the value, the change is explicit in that the customer does not obtain only heat and hot water. Depending on what creates the most value for the customer, a choice can be made between purchasing the products of heat and hot water or a service providing an indoor climate, at a specified indoor temperature level. This flexibility reflects a dematerialization of the district heating offer to meet the challenge of revisited customer requirements. Added service is not a standardized solution but is incorporated on a case-by-case basis and is often triggered by customer requirements. Three of the five companies explicitly offer service package deals on their web pages, and two companies address the importance of supporting the customer to maximize the value of the district heating installation. This is achieved by contacting customers and offering them beneficial reviews of their installations. This approach builds trust and adds value to the district heating purchase. One respondent said that the company offers their customers "sustainability" by extending the offer into new contexts by providing both broadband and charging poles for electrical cars.

The customer relationships of the five case study companies do not reflect the conventional providerpurchaser relationship in district heating, built on the business logic of scale and "push" of products/services towards the customers. Instead, the relationship with the conventional business-to-business customer segment appears to be characterized by dialogue. All five companies share the opinion that customer care and customer retention is extremely important for the future of the business. The CEO of one company points out that "the largest risk for the future business is to not establish a good customer relationship". The business developer of another company finds that the main goal is to retain current customers. The business developer of a third company finds that it is "a large risk if customers are taken for granted and assumed to remain loyal”. This thought is supported by the CEO of the fourth company expressing that the risk of losing customers is, nowadays, very real. Both the CEO and the business developer in the fifth company agree that customer care is extremely important. They also find that customer requests are becoming more demanding and that the time horizon of the customers is short, posing a challenge to the district heating alternative. An important point of departure for all five companies in the quest of establishing a closer customer relationship has been the voluntary "price dialogue". All five companies have been part of the price dialogue since 2016. Two of the companies joined at the start, in 2013. Four out of the five case study companies have revisited their price model as a result of the price dialogue. Once a discussion about the price has been initiated, dialogue about other needs also begins. One example of this is that all five companies provide their customers with support when undertaking energy efficiency investments. In this way, the heat providers become partners to their customers in their energy efficiency undertaking. In three of the companies, key account customers were identified as gaining extra attention and interest from the district heating companies. This is an explicit method for creating a closer relationship with the most important customers. In one of the companies, there is a long-term prosumer relationship, based on industrial excess heat.

The customer channels display new outreach and proactive elements going beyond communication limited to invoice queries and customer complaints. The customer phone is now two-way.

\section{Results: customer interaction (from the review)}

From the 34 research projects of Fjärrsyn, it can be inferred that customer value and customer relationships are addressed by the Swedish frontier of district heating research. This is reflected in the following: increased flexibility in heat delivery, thereby adding value; knowledge building on energy efficiency; price modelling; and the prosumer perspective. Improved data, in 
combination with digitalization, are pointed out as offering yet unexplored potential for improved district heating quality $[54,55]$. Delivery "on demand" creates value through increased flexibility, and engaging in digitalization can be one way for district heating companies to enhance customer value. The request from customers for support in their energy efficiency investments is reflected in knowledge building efforts regarding energy efficiency [81-83], as such knowledge is essential to generate trust. Attention is also given to price modelling [45, 84], and the prosumer possibility of small heat sources is also explicitly addressed [85]. From the 34 research reports, it was also identified that new customer segments and uses of heat are being sought. Increased usage of district heating in industrial processes, for industrial water cleaning, for generating comfort cooling, for inter-seasonal storage and for regional district heating networks, is suggested as pathways for expanding heat demand [86-90].

\section{Results: usage of resources (from the interviews)}

The key district heating resources are still the production plants and distribution networks. The production units in the five case study companies have been newly built and will remain in use for decades. Conventional technology has been applied in these companies, and the business logic is the economies of scale. The changing customer value and relationship build on trust, loyalty and long-term cooperation, and in terms of heat demand, it builds on lower demand. Since the production is based on a logic that is in contrast to the dialogue and trust-based customer value and customer relationship, there is an imbalance in the business model. From the interviews, it is not clear if/how this imbalance is managed. As a result of the changing customer value and relationship, new competencies amongst staff are identified as very important for continued competitiveness. In all five companies, this is reflected by extensive recruitment of competencies other than production, distribution and maintenance.

Key activities are still linked to production, distribution and maintenance. Activities that are gaining in importance are linked to proactive sales and establishing customer dialogue. All five companies confirm that branding has become increasingly important, and it is imperative to be able to display engagement with environmental issues and local commitment. Some of the ways the companies can show such commitment are by supporting circular flows of waste, returning ashes to the forest and cooperating locally with fuel suppliers. In addition to the outreach activities, all five case study companies have looked inward and identified that internal efficiency is essential. It is important to remove old habits and inefficient patterns dating back to the days of public management. The companies act in a competitive market, and there is no room for internal waste. This is reflected in a quote from one of the business developers: "We have introduced process management and have dedicated process managers. Routines, clear roles and transparency have become key".

Key partnerships were limited to fuel providers in the business model canvas of the conventional district heating business. In regard to this, one company has developed its relationship from a standard purchase contract in order to transfer the risk of not having an optimal level of stock at all times to the fuel provider. This transfer necessitates a closer form of interaction between the fuel supplier and the district heating company. The fuel provider enters the internal processes of the district heating company (the fuel provider keeps the stock at an optimum level at all times). Another company has decided to work with local forest owners to secure biofuels. The CEO at this company says: "It was not easy at the beginning, the large providers did not appreciate that we wanted to work with local providers because we were pushing cost down. The cooperation has been good for both us and the forest owners since our demand makes their business model more stable." The third company has had a close relationship over many years with a supplier of industrial excess heat. It has recently entered arrangements with other, selected customers allowing the district heating company to disconnect them at peak load. The remaining two companies have a conventional business-to-business relationship with their fuel suppliers,

Table 5 Aggregation of the collected information on district heating development

\begin{tabular}{|c|c|c|c|}
\hline \multirow[t]{2}{*}{$\begin{array}{l}\text { Key partnerships } \\
\text { Fuel providers } \\
\text { Customers } \\
\text { Policy makers }\end{array}$} & $\begin{array}{l}\text { Key resources } \\
\text { Production unit } \\
\text { Distribution network } \\
\text { Competencies beyond production, } \\
\text { distribution and maintenance }\end{array}$ & $\begin{array}{l}\text { Customer value } \\
\text { Provider of heat and hot water } \\
\text { or of a service } \\
\text { Support } \\
\text { Flexibility } \\
\text { Knowledge on energy efficiency }\end{array}$ & $\begin{array}{l}\text { Customer segment } \\
\text { Business-to-business } \\
\text { (largest segment) } \\
\text { Private home owners } \\
\text { New usage of heat }\end{array}$ \\
\hline & $\begin{array}{l}\text { Key activities } \\
\text { Production } \\
\text { Distribution } \\
\text { Maintenance } \\
\text { Customer engaging } \\
\text { Improved internal efficiency }\end{array}$ & $\begin{array}{l}\text { Customer channel } \\
\text { Invoicing } \\
\text { Campaigns } \\
\text { Customer engaging }\end{array}$ & $\begin{array}{l}\text { Customer relationship } \\
\text { Provider to consumer (push) } \\
\text { Dialogue building trust, loyalty } \\
\text { and long term } \\
\text { Prosumer }\end{array}$ \\
\hline
\end{tabular}


limiting any changes in the relationship to the length of the contract. In summary, the key relationships of the district heating providers are still linked to fuel suppliers. The change is that the relationship itself is strengthening, bringing district heating companies and fuel providers closer.

\section{Results: usage of resources (from the review)}

From the 34 research projects, it was identified that one third are dedicated to improving the functioning of the key resources of production and/or distribution. In addition to the studies mentioned above related to improving the quality of the district heating delivery, factors such as energy efficiency, price model studies, seasonal storage, the prosumer, regional district heating networks and improved functioning of key resources are also reflected in studies of simulated operational efficiency [91], risk management for maintaining the distribution network [92], temperature measurements in liquids [93] and operational life of district heating pipes $[94,95]$. Only one study challenges the current technology by focusing on low-temperature heat supply [40], while three projects address institutional elements $[42,96,97]$. District heating law is also discussed in one of the 34 projects, and it is concluded that this does not promote trust in the district heating system [42]. The impact on district heating of the regulations made by the National Board of Housing, Building and Planning is explored as they impair the competitiveness of district heating compared to other alternatives [97]. Success factors for industrial waste heat cooperation are also addressed, including an analysis of how political, economic and technical factors have impacted cooperation [98].

In Table 5, the collected information on district heating development is aggregated.

Information reflecting the conventional district heating business model is shown in bold. Information from interviews is not bold, and information from the research reports is in italics.

\section{Results and discussion}

The largest change detected in the business models of the case study companies was on the customer side. The customer value is increasingly service oriented, and the customer relationship is switching towards dialogue resulting in trust, loyalty and long-term interaction between district heating companies and their customers. This result implies that business model development in Swedish district heating is primarily driven by external challenges such as competition, energy efficiencies, changing customer demand and an ongoing price dialogue.

The service-oriented development necessitates investments in systems that allow the digitalization of district heating. Over time, it is possible that staff and IT resources will become more important to the district heating business than the conventional production and distribution units. Until this day comes, however, it is clear that transforming the customer-sided components of the business model is one strategy for maintaining the key resource component and the economies of scale logic that is linked to it.

It is identified that change is also spreading into the production- and distribution-oriented parts of the model. For example, the staff is increasingly allocated to internal efficiency improvements. The spread was expected since the different parts of the business models are interconnected. In the literature, the interconnectedness of business model components is, however, pointed out as a potential barrier to business model development. The reason for this is that dominating components can delay a business model shift. The results of this study show that the component of key resources is dominating the business model. Fixed assets are characteristic of utility-sided business models where the value proposition is a bulk generation of heat. Bulk generation of heat is in contrast with both shrinking heat demand and the increased service orientation triggered by changing customer demands. This contrast indicates that one major barrier to business model development in district heating is the key resource component and its logic of economies of scale which is outdated but still preferred.

The volumes of waste that will be recovered in terms of heat will be lower in the future as recovery and recycling of materials increases. Even so, a certain scale of the capacity for waste incineration is needed to efficiently manage waste in the society (from households, official premises and industries). Hence, the utility-sided business model necessitates a certain scale. If the necessary capacity for efficient waste management in society results in a situation where more heat is generated than needed, it is possible to make use of some of the excess heat, by revisiting the key resource component of the business model. For example, many district heating companies have storage units (accumulators) that allow them to shift the usage of generated heat to a later point in time (hours or possibly days) where it is most useful. Improving the storage capacity for longer time spans than days is an ongoing challenge. It would, for example, be very interesting to store heat that is cost-efficiently generated in the summertime and use it in a colder season. Another way to make use of excess heat from waste incineration is to turn heat into cooling to create an offset for heating in, for example, summertime. Flexibility through storage and production of cooling would aid to maintain a viable business. It is important to adjust policymaking from the supposition that the demand for heat is increasing in energy-inefficient buildings to 
understanding the challenges that the industry is facing. The district heating business serves a utility purpose and must be supported as such. In order to remain competitive, incentives for more flexible key resources are important.

With regard to the limitations of this study, no interview questions addressed cost and revenue streams as the respondents did not agree to this kind of information being collected. Two of the nine components of the business model canvas framework reflect revenue and cost. Hence, omitting direct questions about these two components limits the contribution of this study to the understanding of business model development in district heating. Based on the results, it was, however, identified that two of the companies have revisited their approach for securing fuels, and increasing internal efficiency is a factor in all of the companies. Additionally, as a result of customer attention to district heating price, four of the five case study companies revealed that they have revisited their revenue streams by developing their price models from fixed to more variable. This shift reflects a reallocation of business risk from customers to district heating providers, and these changes would have impacted the cost and revenue structure of the companies.

Further research to be performed should address how the key resource component can become more flexible and contribute to managing the challenges that the industry is facing. Also, it is important to identify how costs and revenues are impacted by the management strategies adopted to meet the challenges to the conventional district heating business. This information can then provide input to more efficient business model development in the industry and to more efficient policymaking for the heat market.

\section{Conclusions}

Based on the results of the study, it is concluded that (i) external challenges have resulted in changes in the customer side of the business model, (ii) the key resource component and its logic of production of scale dominate the business model and thereby delay the business development and (iii) the utility (waste management) function of district heating companies necessitates a certain scale of production.

That external challenges have triggered change of the customer components of the business model is new empirical information that supports the notion that business model change is driven by external pressure. That the key resource component is dominant and thereby hinders other business model development provides further evidence to the importance of the interconnectedness of the business model components identified in the literature. The desire to not change the key resource component does, however, not aid the district heating industry to become increasingly competitive. The largest challenge for the companies appears to be a development of the key resource component, making it more flexible to support the management of the new market conditions. The utility function of waste management necessitates a capacity to incinerate municipally generated waste. Accounting for future, shrinking heat demand, all the heat generated from waste incineration might not have an offset. This makes new features of the key resource component crucial. Updated heat market policy should, for example, incentivize increased storage of heat and alternative uses of it (one alternative is cooling). Updated heat market policy should also favour excess heat recovery over new construction of large, conventional production units.

Returning to the challenges in Europe compared to Sweden, it is concluded that shrinking energy demand, in time, also will become an issue in Europe. It is therefore wise to build in flexibility in the key resources of new district heating investments in Europe, accounting for industrial waste heat, storage and alternative offsets for heat.

Returning to the research question, it is concluded that the choice to manage external challenges extends the life of the current business model. This is an approach that can last for a limited period of time, but that does not increase competitiveness. The adjustment to external challenges creates a window of opportunity for the district heating companies to begin the necessary transformation of production and distribution. If this transformation is not undertaken, it is uncertain if district heating will be part of the future energy system.

\section{Acknowledgements \\ The study was possible thanks to the participation of five chief executive officers and five business developers in five Swedish district heating companies. The study was also made possible thanks to the synthesis of the research of Fjärrsyn (2013-2017), the national programm on district heating research in Sweden. The synthesis was financed by Energiforsk.}

\section{Funding \\ Part of the research was funded by Energiforsk (the research programme review), the rest of the research was funded by Halmstad University.}

\section{Availability of data and materials \\ The data supporting the findings of the article are found locally at Högskolan in Halmstad. The interviews made with chief executive officers and business developers will not be shared since it was a requirement for the participants to remain anonymous. The data from the review of the research programme is in Swedish but can be obtained upon request.}

Author's contributions

The author read and approved the final manuscript.

Author's information

The author is affiliated to Halmstad University, the Academy of Engineering and Technology. 


\section{Ethics approval and consent to participate}

All respondents in the study have been informed about the usage of the information they provide through interviews and have given their consent to participate in the study.

\section{Consent for publication}

The respondents of the study have given their consent for the data to be used and published in this scientific article.

\section{Competing interests}

The author declares that she has no competing interests.

\section{Publisher's Note}

Springer Nature remains neutral with regard to jurisdictional claims in published maps and institutional affiliations.

\section{Received: 26 September 2017 Accepted: 3 May 2018}

\section{Published online: 18 June 2018}

\section{References}

1. IEA (2011) Cogeneration and renewables-solutions for a low carbon energy future. OECD/IEA, Paris

2. Di Lucia L, Ericsson K (2014) Low-carbon district heating in Sweden-examining a successful energy transition. Energy Research \& Social Science 4:10-20

3. Commission, E (2016) Comission E (ed) An EU strategy on heating and cooling. Volume ID: COM (2016)51, EU Commission, Brussels

4. Viétor B, Hoppe T, Clancy J (2015) Decentralised combined heat and power in the German Ruhr Valley: assessments of factors blocking uptake and integration. Energy, Sustainability and Society 5:5

5. Persson U, Möller B, Werner S (2014) Heat roadmap Europe: identifying strategic heat synergy regions. Energy Policy 74(Supplement C):663-681

6. Werner S (2017) District heating and cooling in Sweden. Energy 126:419-429

7. Dzebo A, Nykvist B (2017) A new regime and then what? Cracks and tensions in the socio-technical regime of the Swedish heat energy system. Energy Research \& Social Science 29:113-122

8. Lygnerud K, Werner S (2017) Risk of industrial heat recovery in district heating systems. Energy Procedia 116:152-157

9. Lygnerud K (2006) Value creating innovations in the pipeline: a case study of residential house district heating investments in Sweden. BAS, Göteborg

10. Lygnerud K (2010) Risk management in Swedish district heating companies (dissertation). BAS Publishing, Göteborg

11. Lygnerud K (2011) Fjärrvärme S (ed) Fjärrsyn. Minskad Efterfrågan på Fiärrvärme, Stockholm

12. Sweden, S.F.I.A.f.D.H.i., Braschprognos fjärrvärmen 2015. 2010

13. Eriksson L, Morandin M, Harvey S A feasibility study of improved heat recovery and excess heat export at a Swedish chemical complex site. Int J Energy Res

14. Cronholm L-Å, Grönkvist S, Saxe M $(2009,2009)$ Excess heat from industries and premises (Spillvärme från industrier och lokaler). Fjärrsyn report 2011:2

15. Morandin M, Hackl R, Harvey S (2014) Economic feasibility of district heating delivery from industrial excess heat: a case study of a Swedish petrochemical cluster. Energy 65:209-220

16. Brange $L$ (2015) Technical and environmental analysis of prosumers in district heating networks. Licentiate thesis. Lund university, Lund

17. Brange $L$ et al (2016) Prosumers in district heating networks a Swedish case study. Appl Energy 164(15):492-500

18. Chesborough H (2010) Business model innovation, opportunities and barriers. Long Range Plan 43:354-363

19. Sosna $\mathrm{M}$ et al (2010) Business model innovation through trial and error learning: the Naturhouse case. Long Range Plan 43:383-407

20. Bouchikhi H, Kimberly J (2003) Escaping the identity trap. MIT Sloan Management Revies 44(3):20-26

21. Werner S, Frederiksen F (2013) District heating and cooling Studentlitteratur, Lund

22. Energiföretagen Sverige (2017) Fjärrvärmens miljönytta. www. energiforetagen.se

23. Werner S (1991) District heating in Sweden 1948-1990. Fernwärme Int 20: 603-616

24. Hall T, Viden S (2005) The Million Homes Programme: a review of the great Swedish planning project. Planning Persprctive 2005(20):301-328
25. Haegermark H (2001) Priorities of energy research in Sweden in Silviera s., building sustainable energy sustem,s- Swedish experiences, pp 163-195

26. Wickman K (1988) The energy market and energy policy in Sweden 1965-1984. Energy 13:83-96

27. Government, P.b.t.S., Regeringens proposition 1987/88:85 om miljöpolitiken inför 1990-talet. 1987, 1988

28. Sweden, S., Annual energy statistics (electricity, district heating and gas). 2016

29. Berge A, Adl-Zarrabi B (2017) Long term performance of vacuum insulation panels in hybrid insulation district heating pipes. Energy Procedia 116(Supplement C):334-342

30. Ljungblad S, Holmsten M, Franzén T (2015) Temperaturmätning i vätskeflöden In: Svensk fjärrvärme. Rapport 2015:118

31. Rosén T, Ödlund L (2017) Storskalig styrning av fjärrvärme. Fjärrsyn report 2017:413

32. Sernhed K, Lygnerud K, Werner S (2017) En syntes av Fjärrsyn 2013-2017. Fjärrsyn report 2017:425

33. Meggers F, Hansjurg L (2010) The potential of wastewater heat and exergy: decentralized high-temperature recovery with a heat pump. Energy and Buildings 43(4):879-886

34. Shen C, Jiang Y, Yao Y, Wang X (2012) An experimental comparison of two heat exchangers used in wastewater source heat pump: a novel dryexpansion shell-and-tube evaporator versus a conventional immersed evaporator. Energy 47(1):600-608

35. Cipolla S, Maglionico M (2014) Heat recovery from urban wastewater: analysis of the variability of flow rate and temperature in the sewer of Bologna, Italy. Energy Procedia 45:288-297

36. Avgerinou $\mathrm{M}$, Bertoldi $\mathrm{P}$ et al (2017) Trends in data centre energy consumption under the European code of conduct for data centre energy efficiency. Energies 10(1470), doi:https://doi.org/10.3390/en10101470

37. Davies GF et al (2016) Using data centres for combined heating and cooling: an investigation for London. Appl Therm Eng 94:296-304

38. Ebrahimi $\mathrm{K}$ et al (2014) A review of data center cooling technology, operating conditions and the corresponding low-grade waste heat recovery opportunities. Renew Sust Energ Rev 31:622-638

39. Wahlroos $M$ et al (2017) Utilizing data center waste heat in district heating-impacts on energy efficiency and prospects for low-temperature district heating networks. Energy 140:1228-1238

40. Werner S, Averfalk H (2017) Framtida Fjärrvärmeteknik. Svensk Fjärrvärme 2017:419

41. Westin P, Lagergren F (2002) Re-regulating district heating in Sweden. Energy Policy 30:583-596

42. Hult D (2016) Kan man skapa förtroende med lagstiftning? En analys av fjärrvärmelagens potential att skapa förtroende. Energiforsk AB, Stockholm

43. Holm J (2013) Inför prisregleringen av fjärrvärme. Swedish Competition Authority 2013:1

44. Ryden B et al (2013) Fjärrvärmens affärsmodelller. Svensk Fjärrvärme, Stockholm

45. Gåverud H (2016) Kundernas uppfattning om förändrade prismodeller. Fiärrsyn 2016:301

46. SOU (2011) Fjärrvärme i konkurrens. Statens Offentliga Utredningar 2011:44

47. Thyselius E (2016) Förtryckande fjärrvärme/Oppressing district heating. Småladsposten, Public Press, Växjö

48. Nilsson, T, Dyrt med tveksamt fjärrvärmetvång/Expensive with forced district heating 2009

49. Boverkets byggregler 2011:6- föreskrifter och allmänna råd, BFS 2011:16

50. Sköldberg H, Haraldsson M, Johnsson J, Rydén B, Göransson A, Holmström D, Löfblad E, Unger T (2011) Konkurrenssituation i ett framtida hållbart energisystem. Fjärrsyn report 2011:2

51. Agency SE (2015) Värmepumparnas roll på uppvärmningsmarknaden. ER:09

52. Persson U, Werner $S$ (2011) Heat distribution and the future competitiveness of district heating. Appl Energy 88(3):568-576

53. Magnusson D (2012) Swedish district heating - a system in stagnatin: current and future trends in the district heating sector. Energy Policy 48:449-459

54. Gadd H, Werner S (2015) Framtida värmebehov etapp 2. Fjärrsyn 2015:107

55. Emanuel J et al (2016) Gröna IT innovationer för fjärrvärme. Fjärrsyn 2016:313

56. Groth P, Nielsen C (2013) Constructing a business model taxonomy: using statistical tools to generate a valid and reliable business model taxonomy. Journal of Business Models 3(1):4-21

57. Schaltegger $\mathbf{S}$ et al (2012) Business cases for sustainability: the role of business model innovation for corporate sustainability. International Journal of Innovation and Sustainable Development 6(2):95-117 
58. Ostewalder A, Pigneur Y (2010) Business model generation. Self published book Wiley, New York

59. Teece D (2010) Business models, business strategy and innovation. Long Range Plan 43:172-194

60. Casadesus-Mansanell R, Richart J (2010) From strategy to business models and to tactics. Long Range Plan 43:48-55

61. Markides C, Charitou C (2004) Competing with dual business models: a contingencyapproach. The academy of management executive 1993-2005 18(3):22-36

62. Morris M et al (2005) The entrepreneurs' business model: toward a unified perspective. J Bus Res 58:726-735

63. Margretta J (2002) Why business models matter. Harv Bus Rev 80:3-8

64. Christensen C (2001) The past and future of competitive advantage. MIT Sloan Management Revies 42(2):105-109

65. Zott C, Amit R (2008) The fit between product market strategy and business model: implications for firm performance. Strateg Manag J 29(1):1-29

66. Demil B, Lecocq X (2010) Business model evolution: in search of dynamic consistency. Long Range Plan 43:227-246

67. Johnson M-W et al (2008) Reinventing your business model. Harv Bus Rev 86:50-59

68. Johnson M (2008) Reinventing your business model. Harv Bus Rev 86:50-59

69. Björkdahl J (2009) Technology cross-fertilization and the business model: the case of integrationg ICTs in mechanical engineering products. Res Policy 38:1468-1477

70. Giesen E (2007) Path to success, three ways to innovate your business model. IBM, Institute for business value 23:436-438

71. Martins L et al (2015) Unlocking the hidden value of concepts: a manageria cognition perspective on business models and business model innovation. Strateg Entrep J 9(1):99-117

72. Eurich M (2014) A six step approach to business model innovation. Internatinal Journal of Entrepreneurship and Innovation Management 18(4): 330-48

73. Blank, S., Dorf, B, The startup owners manual — the step by steo guide for building a great company. 2012

74. Frankenberger $\mathrm{K}$ et al (2013) The 4l-framework of business model innovation: a structured view on process phases and challenges. International journal of product development 18:3-4

75. Sheehan T, Stabell C (2007) Discovering new business models for knowledge intensive organizations. Strategy and leadership 35(2):22-29

76. Richter M (2013) Business model innovation for sustainable energy: German utilities and renewable energy. Energy Policy 62:1226-1237

77. Okkonen L, Suhonen N (2010) Business models of heat entrepreneurship in Finland. Energy Policy 38:3443-3452

78. Corvellec H, Bramryd T, Hultman J (2012) The business model of solid waste management in Sweden-a case study of two municipally owned companies. Waste Manag Res 30:512-518

79. Flyvbjerg B (2006) Five misunderstandings about case study research. Quantitative inquiry 12(2):219-245

80. Galetta A (2013) Mastering the semistructured interview and beyond. New York University Press, New York

81. Åberg, M., Nya lösningar för fjärrvärme i miljonprogram. Fjärrsyn 2017 2017:414

82. Pädam S et al (2016) Samband mellan innemiljö, energieffektivisering och fjärrvärmeproduktion. Fjärrsyn:305

83. Hagberg, M., Strategier för hållbar energieffektivisering. 2017. Fjärrsyn 2017:416

84. Hailong, L., Dynamisk prismekanism baserad på förutsägelsen av värmebehovet. 2017. Fjärrsyn 2017:408

85. Lauenberg, P., Små värmekällor- kunden som prosument. 2016. Fjärrsyn 2016:289

86. Steen, K.-M., Att använda fjärrvärme i industriprocesser. 2015. Fjärrsyn 2015:155

87. Woldemariam, D.et al., Fjärrvärmedriven vattenrening i industrin. 2016. Fjärrsyn 2016:229

88. Wallenun, H., Värmedriven komfortkyla för mindre anläggningar. 2015. Fjärrsyn 2015:184

89. Lindström, E., Fastighetsnära säsongslagring av fjärrvärme. 2016. Fjärrsyn 2016:321

90. Nohlgren, I., Regionala fjärrvärmesamarbeten. 2015. Fjärrsyn 2015:102

91. Trygg, L., Storskalig styrning av fjärrvärme. 2017. Fjärrsyn 2017: 413

92. Jönsson, M., Riskhantering för underhåll av fjärrvärmenät. 2015. Fjärrsyn 2015: 185

93. Ljungblad, S., Temperaturmätning i vätskeflöden. 2015. Fjärrsyn 2015:118
94. Bijan, A.-Z., Livslängd och statusbedömning av fjärrvärmenät. 2017. Fjärrsyn 2017:420

95. Nazdaneh, Y., Livslängd för fjärrvärmerör. 2017. Fjärrsyn 2017:354

96. Söderberg C et al (2017) Resurseffektiva städer. Fjärrsyn 410:2017

97. Norrman Eriksson, O., Karlsson, B, Regelstyrd miljö- och energivärdering av byggnader. 2017:411, 2017

98. Wårell, L., Resurseffektiva städer. 2017. Fjärrsyn 2017: 410

\section{Submit your manuscript to a SpringerOpen ${ }^{\circ}$ journal and benefit from:}

- Convenient online submission

- Rigorous peer review

- Open access: articles freely available online

- High visibility within the field

- Retaining the copyright to your article

Submit your next manuscript at $>$ springeropen.com 